Artvin Çoruh Üniversitesi

Orman Fakültesi Dergisi

ISSN:2146-1880, e-ISSN: 2146-698X

Yıl: 2017, Cilt: 18, Sayı:1, Sayfa:88-97

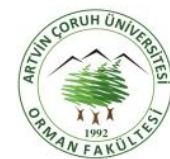

ofd.artvin.edu.tr

(c) $($ )
Artvin Coruh University

Journal of Forestry Faculty

ISSN:2146-1880, e-ISSN: 2146-698X

Year: 2017, Vol: 18, Issue: 1, Pages:88-97

\title{
Mobilya endüstrisinde çalışanların iş doyumu ile iş performansı arasındaki ilişkinin araştırılması
}

\section{The investigation of the relationship between the job satisfaction and job performance of employees in furniture sector}

Türkay TÜRKOĞLU1, Ümüt YURDAKUL²

${ }^{1}$ Muğla Sıtkı Koçman Üniversitesi, Köyceğiz Meslek Yüksekokulu, Ormancılık Bölümü, Muğla, Türkiye

2 Muğla Sıtkı Koçman Üniversitesi, Fen Bilimleri Enstitüsü, Ağaçişleri Endüstri Mühendisliği ABD, Muğla, Türkiye

\section{Eser Bilgisi / Article Info}

Araştırma makalesi / Research article

DOI: 10.17474 /artvinofd.270325

Sorumlu yazar / Corresponding author

Türkay TÜRKOĞLU

e-mail: turkayturkoglu@mu.edu.tr

Geliş tarihi / Received

29.11.2016

Düzeltme tarihi / Received in revised form

22.02.2017

Elektronik erişim / Online available

23.03.2017

Anahtar kelimeler:

Mobilya endüstrisi

iş doyumu

Iş performansı

Demografik özellikler

Çalışanlar

Keywords:

Furniture Industry

Job satisfaction

Job Performance

Demographic characteristics

Employees

\begin{abstract}
Özet
Mobilya endüstrisinde çalışanların el emeği ve performansları ürünlerin kalitesinin oluşmasında büyük öneme sahiptir. Çalışanlardan yüksek performans elde edebilmesi için onların iş doyumunun sağlanması gerekmektedir. Bu araştırmada örgütler için son derece önemli bir yönetsel durum olan iş doyumu veya doyumsuzluğunun işgörenlerin performansı üzerindeki etkisinin belirlenmesi amaçlanmaktadır. Çalışmada, birçok araştırmada kullanılan geçerliliği test edilmiş "Minnesota iş̧ Tatmin Ölçeği" ve "iş̧ören Performans Ölçeği" kullanılmıştır. Bu doğrultuda, mobilya sektöründe çalışan 362 kişiye anket uygulanmıştır. Elde edilen verilere SPSS programında Bağımsız Örneklem tTesti ve Tek Yönlü Varyans Analizi (ANOVA) testi, Korelasyon ve Regresyon Analizleri uygulanmıştır. Araştırma sonucunda çalışanların iş doyumu ve doyumsuzluğu ile performansları arasında kuvvetli bir ilişki olduğu tespit edilmiştir. Cinsiyet, yaş, eğitim durumu ve kıdem gibi bazı demografik özelliklere göre iş doyumu ve iş performanslarında anlamlı farklılıklar bulunurken, medeni duruma göre önemli bir fark bulunamamıştır.
\end{abstract}

\begin{abstract}
Manpower and performance of employees in furniture industry plays an important role in the quality of the products. It is necessary to ensure the job satisfaction of employees to achieve their high performance. "The Minnesota Job Satisfaction Scale" and "the Job Performance Scale" were used as data collection tools in the study. Therefore, questionnaire form was conducted on 362 employees of furniture sector. Obtained data was analyzed in SPSS program by means of Correlation and Regression Analyses, $t$-test and ANOVA. The result of the study shows that there is a strong relationship between job satisfaction and employees performance. While there were significant differences in job satisfaction and job performance in term of some employees' demographic characteristics such as gender, age, educational status and seniority, it wasn't found significant difference in marital status.
\end{abstract}

\section{GiRiş}

Günümüz ekonomik rekabet ortamı içerisinde işletmelerin temel amacı verimliliklerini ve kârlııklarını maksimuma ulaştırmaktır. $\mathrm{Bu}$ amacı gerçekleştirebilmenin en etkili yolu çalışanların performans ve iş tatminleri ile işletmelerin beklentilerini uyumlu hale getirebilmektir (Tekeli ve Paşaoğlu 2012). Çalışanların işletme içerisinde etkin ve verimli olarak çalışmaları ise büyük ölçüde yüksek iş tatminine sahip olmalarına bağlıdır. Yine iş tatminini çalışma koşullarının kötü olması ve tatminkar bir ücretin elde edilememesi, takdir edilmeme ve sosyal prestij eksikliği gibi faktörlerin etkilediği belirtilmektedir (Bozkurt ve Bozkurt 2008). Bu sebeple, işletmelerin çalışanların iş tatminini etkileyen faktörleri belirlemesi ve bunların iyileştirilmesi için çaba harcaması büyük önem taşımaktadır (Quick ve Nelson 1995). Çalışanların verimliliğini ve performansını en üst düzeye çıkartmak için çalışanların işlerinde tatmin olmaları sağlanmalı ve hayal kırıklığına uğramaları önlenmelidir. İşin tatminsizliği durumunda, düşük performans, devamsızlık ve işgücü devrinde artış gibi olumsuzluklar ortaya çıkmaktadır (Noe ve ark. 1997; Erdil ve ark. 2011). İş doyumu, bireyin işi ve işyeri hakkındaki genel duygu, düşünce kalıpları hakkında fikir verebilecek önemli bir değişkendir. Diğer bir ifade ile iş doyumu, bireyin işyerine yönelik beklentilerini ve işine yönelik tutumunu ifade etmektedir. İş doyumu denince, işten elde edilen maddi çıkarlar, çalışanın birlikte çalışmaktan zevk aldığı iş arkadaşları ve üretim yapmanın sağladığı bir mutluluk akla gelmektedir (Akşit Aşık 2010). 
Duygusal bir durum olan iş doyumu, işi tutkuyla yapmak gibi bireysel, kararlara katılmak gibi toplumsal etkenlere bağlıdır (Yıldırım 1995). İs doyumunun sağlanması işletmelerdeki çalışanların yerine getirecekleri faaliyetlerin kalitesinde önemli bir etkiye sahiptir. Bu nedenle işletmeler, çalışanların iş doyumlarını artırmak için çeşitli yönetsel yöntem ve teknik kullanmaktadır. İ̧ doyumunu artırıcı çabaların sonucunda ise, yüksek seviyede doyuma ulaşmış çalışanların performans ve etkinliklerinde olumlu gelişmeler sağlanabilmektedir (Sevimli ve İşcan 2005). İşletmelerde arzu edilen düzeyde bir etkinliğin sağlanabilmesi için performansın yönetilmesi çok önemlidir. Performans kavramı işletmelerde çalışan birey veya grupların işletme hedefine ulaşabilmek için oluşturdukları çabalar olarak ifade edilebilir. Bu nedenle işletmeler yalnızca çalışanlarının göstermiş oldukları performansla doğru orantılı olarak başarılı olabilirler (Yılmaz ve Karahan 2010). Performansı yüksek çalışanlar işletme performansını arttırmakta ve bu artış işletmeler için vazgeçilmez öneme sahip olan rekabet gücünü yükseltmektedir (Turunç 2010; Yılmaz ve Karahan 2010). Performans yönetimi ise, işletmelerin personel yönetimi, finansal ve fiziksel kaynaklarının arzu edilen verimlilik düzeyine ulaşmasını ve bunun sürdürülebilir şekilde sağlanması sürecidir. Ayrıca, performans yönetimiyle takım performansı iyileştirilmekte ve kurumsal başarının ortaya çıkarılması sağlanmaktadır (Tutar ve Altınöz 2010).

Mobilya sektörü, son on yıllık süreçte uluslararası pazarlara açılmış ve bu alandaki gelişimini en hızlı şekilde yürütmektedir. Sektörün gelişimi ile birlikte sağladığı istihdam, oluşturduğu katma değer ve kapasite kullanımı gibi faktörler açısından Türkiye ekonomisinde önemli bir değer durumuna gelmiştir (Anonim 2013a). Türkiye ekonomisi açısından mobilya sektörünün önemi; üretim aşamasında yerli kaynaklardan yararlanılması ve sektörün dışa bağımlılığının çok düşük düzeyde olmasıdır (Türkoğlu ve Tolunay 2013; Tolunay ve Türkoğlu 2014). Bu durum, sektörü katma değer anlamında daha verimli hale getirmektedir. Türk mobilya sektörü rağbet gören iş alanı olduğu zamandan bu yana, insan gücü ve kalitesi önemli bir girdi olarak kabul edilmektedir (Toker ve ark. 2016). Günümüzde, sektörde faaliyet gösteren işletme sayısının yaklaşık 30.000 civarında olduğu tahmin edilmekte, bu işletmelerde yaklaşık 250.000 kişinin istihdam edildiği belirtilmektedir. Sektörün önemli bir bölümünü geleneksel çalışma yöntemlerinin geçerli olduğu "küçük işletmeler" oluşturmaktadır (Anonim 2013b). Türkiye'de özellikle son dönemde küçük ölçekli işletmelerin yanı sıra, orta ve büyük ölçekli işletmelerin sayısının artmasıyla birlikte teknolojik olarak da önemli bir gelişme sağlamıştır (Toker ve ark. 2016). Düşük teknoloji ve sermaye ile emek yoğun faaliyet gösterdiği düşünülen mobilya sanayii, son yıllarda hızlı bir dönüşüm geçirerek geçmiş yıllara oranla çok daha bilgi ve sermaye yoğun bir sektör olma yolunda ilerlemiştir. Türker ve Gavcar (1993) tarafından 1985 yılı verilerine göre yapılan orman ürünleri endüstrisi sektörü (Ağaç ve mantar ürünleri, ağaç mobilya ve mefruşat sanayi ile kağıt ve kağıt ürünleri sektörü) analizinde 64 sektörün yer aldığı imalat sanayi içindeki payı \% 2 olarak belirtilirken, günümüzde ise sadece mobilya sanayinin payı \%3'lük bir orana ulaştığı belirtilmektedir (Anonim 2015a). Sektörün ülke coğrafyasındaki konumlanışı ise başta Kayseri ve İstanbul olmak üzere İzmir, Bursa, Ankara, Adana, Düzce gibi illerde yoğunlaşmaktadır. Onuncu Kalkınma Planı, Sürdürülebilir Orman Yönetimi Özel İhtisas Komisyonu Raporuna göre Mobilya sektörü, katma değerinin yüksek olması, ileri bağlantılarıyla diğer sektörler için önem arz etmesi ve özellikle ahşap mobilya dış ticaretinde Türkiye'de ihracatçı durumunda olması sebebiyle ülkemiz orman yönetimini de uyarıcı etkiler oluşturabilecek önemde olduğu vurgulanmıştır (Anonim 2015b).

$\mathrm{Bu}$ çalışma, iş doyumunun işletmelerin temel unsuru olan insan kaynaklarının etkinliğinin ve performansının artırılmasında önemli bir rol oynayacağı düşüncesinden hareketle ortaya çıkmış ve yukarıda bahsedilen sebeplerden dolayı ülkemiz açısından önemli bir sektör olan mobilya endüstrisinde ele alınmıştır. Bu nedenle araştırmanın temel amacı mobilya sektöründe çalışanların iş doyumu ile iş performansları arasındaki ilişkinin incelenmesini içermekte ve iş doyumu ile iş performansının çalışanların bazı demografik özelliklere göre farklılık gösterip göstermediğinin belirlenmesidir. 


\section{MATERYAL VE YÖNTEM}

Araştırmanın evrenini, Türkiye'de Mobilya Endüstrisinde çalışan personel oluşturmakta olup, Mobilya Sektörü Raporuna göre 250.000 kişi olduğu tahmin edilmektedir. Anket uygulaması, i̇stanbul, Kayseri, Çanakkale, Düzce ve Denizli illerinde bulunan ülkemizin önemli mobilya firmalarında çalışan kişilere, 2016 yılı Ocak-Haziran ayları arasında uygulanmıştır. Bu sebeple araştırmanın örneklemini rasgele örnekleme yöntemi ile ulaşılabilen çalışanlar oluşturmuştur. Anket uygulamasında örnek büyüklüğ̈̈;

$\left[\mathrm{N} * \mathrm{t}^{2} * \mathrm{p} * \mathrm{q}\right] /\left[\mathrm{d}^{2} *(\mathrm{~N}-1)+\mathrm{t}^{2} * \mathrm{p} * \mathrm{q}\right]$ eşitliğinden hesaplanmıştır (Baş 2005).

Burada örnekleme alınacak sayı (n), ana kütle büyüklüğü (N), güven kat sayısı (t: \%95'lik güven için bu katsayı 1,96 alınmaktadır), ölçmek istediğimiz özelliğin ana kütlede bulunma ihtimali (p), ölçmek istenilen özelliğin ana kütlede bulunmama intimali (q) ve kabul edilen örnekleme hatası (d: \% 10)'dir. Bu formüle göre;

$\left.\mathrm{n}=250.000 * 1.96^{2} * 0,5 * 0,5\right] /\left[0,10^{2} *(250.000-1)+\right.$ $\left.1.96^{2} * 0,5 * 0,5\right]=96$ kişi olarak bulunmuştur. Çalışmaya 250 kişi katılırken, hatalı doldurulan ve geçersiz olan formların çıkarılması neticesinde 210 anket formu değerlendirmeye alınmıştır. Araştırma ilişkisel tarama modelindedir. iliş̧kisel tarama modeli, iki ve daha çok sayıdaki değişken arasında birlikte değişim varlığını veya derecesini belirlemeyi amaçlayan araştırma modelidir. Araştırmanın bağımlı değişkenleri; mobilya sektöründe çalışan personelin iş doyumları ile iş performansları, bağımsız değişkenlerini ise; yaş, cinsiyet, medeni durum, eğitim düzeyi ve çalışma süresi oluşturmaktadır. Araştırmaya katılan personele ait veriler anket tekniği vasıtasıyla elde edilmiştir. Araştırmada kullanılacak anket formları, kişisel bilgileri içeren demografik sorulardan, Minnesota iş Doyumu Ölçeğinden (MiDÖ) ve İşgören Performans Ölçeğinden (IPÖ) oluşmaktadır. Ölçeklerdeki maddelerin değerlendirilmesinde $5^{\prime}$ li likert tipi beşli dereceleme ölçeği kullanılmaktadır. MiDÖ, Weiss ve arkadaşları tarafından 1967 yılında geliştirilmiş olup, Deniz ve Güliz Gökçora (1985) tarafından Türkçeye çevrilmiş ve birçok araştırmada kullanılmıştır. Çalışanların performanslarını ölçmek amacı ile önce Kirkman ve Rosen
(1999), daha sonra, Sigler ve Pearson (2000) tarafından yapılan çalışmalarda kullanılıış olan 4 maddelik iPÖ kullanılmıştır. Ölçek, Türkçe'ye, Çöl (2008) tarafından uyarlanmıştır. Ölçekler, ülkemizde de bazı ormancılık araştırmalarında kullanılmıştır (Yılmaz ve Koçak 2008; Yılmaz vd. 2009).

Elde edilen verilerin istatistiksel çözümlemeleri SPSS 20 (Statistical Packet for the Social Sciences) programında gerçekleştirilmiştir. Verilerin çözümlenmesi sürecinde öncelikle demografik bilgilere ait betimleyici frekans ve yüzde dağılımları çıkarılmıştır. İş doyumu ve performans arasındaki ilişkinin şiddetin belirlenmesi için korelasyon analizinden ve fonksiyonel şeklinin belirlenmesinde ise regresyon analizinden faydalanılmıştır. Araştırmanın alt boyutlarının çözümlenmesinde katılımcıların demografik özelliklerine göre (yaş, cinsiyet, medeni durum, eğitim düzeyi ve çalışma süresi) gruplar arasında anlamlı bir farkın bulunup bulunmadığının belirlenmesi amacıyla “Bağımsız Örneklem t testi” ve "Tek Yönlü Varyans Analizı (ANOVA)" yapılarak yorumlanmıştır. Farkın hangi gruplar arasında olduğunu belirlemek için çoklu karşılaştırmalar testi olan Duncan testi uygulanmıştır. İstatiksel çözümlemelerdeki anlamlılık düzeyi $\mathrm{P}<0.05$ olarak kabul edilmiştir. Çalışmadaki verilerin güvenilirliğini ölçmek için Cronbach's Alpha değerinden faydalanılmış ve 0,920 değeri bulunmuştur. Bu değerin 0,80-1,00 arasında bulunması verilerin yüksek güvenilirlikte olduğunu göstermektedir (Akgül ve Çevik 2005).

Araştırma kapsamında oluşturulan ve test edilen hipotezler şunlardır;

$\mathrm{H}_{1}$ : Çalışanların cinsiyetine göre iş doyumları ve iş performansları arasında fark vardır.

$\mathrm{H}_{2}$ : Çalışanların medeni durumuna göre iş doyumları ve iş performansları arasında fark vardır.

$\mathrm{H}_{3}$ : Çalışanların yaşlarına göre iş doyumları ve iş performansları arasında fark vardır.

$\mathrm{H}_{4}$ : Çalışanların eğitim durumlarına göre iş doyumları ve iş performansları arasında fark vardır.

$\mathrm{H}_{5}$ : Çalışanların sektörde çalışma süresine göre iş doyumları ve iş performansları arasında fark vardır.

$\mathrm{H}_{6}$ : Çalışanların işletmelerinin bulundukları illere göre iş doyumları ve iş performansları arasında fark vardır. 
$\mathrm{H}_{7}$ : Mobilya sektöründe çalışan personellerin iş doyum düzeyleri ile iş performansları arasında doğrusal bir ilişki vardır.

\section{BULGULAR}

\section{Araştırmaya katılan kişilerin demografik özellikleri}

Bu kısımda, işletmelerin bulunduğu şehirlerin araştırmaya katılan kişilere göre oranları, çalışanların cinsiyetleri, yaşları, eğitim seviyeleri, medeni durumları ve sektördeki çalışma sürelerine ilişkin frekans dağılımları $(f)$ ve yüzdeleri (\%) Tablo 1'de verilmiştir.

Araştırmaya katılanların demografik özellikleri açısından dağılımına bakıldığında; \% 87.6'sının bay, \% 12.4'ü bayan,
\% 64.1'i evli, \% 35.9'u bekar olduğu, \% 46.1'i 26-35 yaş aralığında, \% 25.7'si 36-45 yaş aralığında, \% 18.8'i 18-25 yaş aralığında ve \% 9.4'ü 46 yaş ve üzeri olduğu görülmüştür. Çalışma süreleri açısından ise \% 44.8'i 0-5 yıl aralığında, \% 20.7'si 6-10 yıl aralığında, \% 15.5'i 20 ve üzeri, \% 13.5’i 11-15 yıl aralığında ve \% 5.5'i 16-20 yıl aralığında yer almaktadır. Eğitim düzeyleri açısından ise \% 34.5'i lise, \% 21.3'ü lisans, \% 17.1'i ikokul, \% 13'ü ortaokul, \% 11.9'su önlisans ve \% 2.2'si lisansüstü mezunudur. Diğer yandan araştırmaya katılan çalışanların işletmelerin bulunduğu yer (il bazında) dağılımına göre, işletmelerin \% 37.5'i İstanbul'da, \% 22.7'si Kayseri'de, \% 15.5'i Düzce'de, \% 15.5'i Çanakkale'de ve \% 9.4'ü Denizli ilinde bulunmaktadır.

Tablo 1. Araştırmaya katılan kişilerin demografik özellikleri

\begin{tabular}{|c|c|c|c|c|c|}
\hline Cinsiyet Dağılımı & Sayı (f) & Yüzde (\%) & Medeni Durumu & Sayı (f) & Yüzde (\%) \\
\hline Bayan & 45 & 12.4 & Evli & 232 & 64.1 \\
\hline Bay & 317 & 87.6 & Bekar & 118 & 35.9 \\
\hline Toplam & 362 & 100.0 & & 362 & 100.0 \\
\hline Yaş Dağııımı & Sayı (f) & Yüzde (\%) & Çalışma süresi & Sayı (f) & Yüzde (\%) \\
\hline $18-25$ & 68 & 18.8 & $0-5$ yıl & 147 & 44.8 \\
\hline $26-35$ & 167 & 46.1 & $6-10 \mathrm{yıl}$ & 68 & 20.7 \\
\hline $36-45$ & 93 & 25.7 & $11-15$ yıl & 44 & 13.5 \\
\hline \multirow[t]{2}{*}{46 ve üzeri } & 34 & 9.4 & $16-20 \mathrm{yll}$ & 18 & 5.5 \\
\hline & & & 20 ve üzeri & 51 & 15.5 \\
\hline Eğitim düzeyi & Sayı (f) & Yüzde (\%) & Katılımcıların çalıştıkları & Sayı (f) & Yüzde (\%) \\
\hline ilkokul & 62 & 17.1 & işletmelerin ili & & \\
\hline Ortaokul & 47 & 13.0 & Düzce & 54 & 14.9 \\
\hline Lise & 125 & 34.5 & İstanbul & 136 & 37.5 \\
\hline Önlisans & 43 & 11.9 & Çanakkale & 56 & 15.5 \\
\hline Lisans & 77 & 21.3 & Kayseri & 82 & 22.7 \\
\hline Lisansüstü & 8 & 2.2 & Denizli & 34 & 9.4 \\
\hline Toplam & 362 & 100.0 & Toplam & 362 & 100.0 \\
\hline
\end{tabular}

İş doyumu ve iş performansının çalışanların bazı özelliklerine göre farklılık denetimi

Araştırmaya katılanların cinsiyet değişkeni açısından iş doyumu ve iş performanslarında ortaya çıkarmak için yapılan bağımsız örneklem t Testi sonuçları Tablo 2'de gösterilmiştir.

Tablo 2. Cinsiyet değişkenine göre ortalama farkları

\begin{tabular}{lllllll}
\hline & Cinsiyet & N & Ortalama & Std. Sapma & t & P \\
\hline iş Doyumu & Bayan & 45 & 2.8611 & 1.01073 & -3.317 & $0.001^{*}$ \\
İş Performansı & Bay & 317 & 3.2569 & 0.70495 & & \\
& Bayan & 45 & 3.7667 & 0.79129 & $0.037^{*}$ & \\
\hline
\end{tabular}

$* \mathrm{P}<0.05$

Tablo 2'den de anlaşılacağı üzere, araştırmaya katılanların cinsiyet değişkenleri açısından iş doyumu ve iş performans ortalamalarında farklılığın olup olmadığına bakılmış olup, 0.05 önem seviyesinde cinsiyete göre iş doyumu ve iş performanslarının farklı olduğu tespit edilmiştir. Bu durumda, çalışanların cinsiyetine göre iş doyumları ve iş performansları arasında fark vardır hipotezi kabul edilmiştir. 
Araştırmaya katılanların medeni durumu değişkenine göre iş doyumu ve iş performanslarında bir farklılığın olup olmadığı bağımsız örneklem t Testi ile yapılmış olup, Tablo 3'de gösterilmiştir. Medeni durum değişkenine göre 0.05 önem seviyesinde bir farklılaşmaya rastlanmamıştır. Böylece, çalışanların medeni durumuna göre iş doyumları ve iş performansları arasında fark olmadığı anlaşılmış ve araştırmanın $\mathrm{H}_{2}$ hipotezi reddedilmiştir.

Tablo 3. Medeni durumu değişkenine göre ortalama farkları

\begin{tabular}{llccccc}
\hline \multicolumn{2}{c}{ Medeni Durum } & N & Ortalama & Std. Sapma & t & P \\
\hline \multirow{2}{*}{ iş Doyumu } & Evli & 232 & 3.1647 & 0.72294 & -1.444 & \multirow{2}{*}{0.150} \\
& Bekar & 130 & 3.2846 & 0.81761 & & \\
iş Performansı & Evli & 232 & 3.9181 & 0.78147 & -1.936 & \multirow{2}{*}{0.054} \\
\hline
\end{tabular}

Araştırmaya katılanların yaş dağılımı değişkenine göre yapılan Varyans Analizi sonuçları Tablo 4'de gösterilmiştir. İş doyumu ve iş performanslarında bir farklılaşmanın olup olmadığı 0.05 önem seviyesinde iş performansı değişkeni ortalamalarında bir farklılaşma bulunamazken, iş doyumu değişkeni açısından 0.05 önem seviyesinde bir farklılaşma tespit edilmiştir. Farklılaşmanın hangi yaş grubundan kaynaklandığını bulmak için yapılan Duncan testinde ise 46 ve üzeri yaşa sahip kişilerin iş doyumlarının diğer yaş gruplarına göre daha az olduğu tespit edilmiştir. Bu durumda, çalışanların yaşlarına göre iş doyumları arasında fark olduğu tespit edilerek, $\mathrm{H}_{3}$ hipotezi kabul edilmiştir.

Tablo 4. Yaş dağılımı değişkenine göre ortalama farkları

\begin{tabular}{|c|c|c|c|c|c|c|}
\hline \multicolumn{2}{|l|}{ Yaş Aralıkları } & $\mathbf{N}$ & Ortalama & Std. Sapma & $\mathbf{F}$ & $\mathbf{P}$ \\
\hline \multirow{5}{*}{ İş Doyumu } & $18-25$ & 68 & 3.3309 & 0.71268 & \multirow{5}{*}{3.217} & \multirow{5}{*}{$0.023^{*}$} \\
\hline & $26-35$ & 167 & 3.1144 & 0.79912 & & \\
\hline & $36-45$ & 93 & 3.3505 & 0.72496 & & \\
\hline & 46 ve üzeri & 34 & 3.0294 & 0.65852 & & \\
\hline & Genel ortalama & 362 & 3.2077 & 0.75936 & & \\
\hline \multirow{5}{*}{ İş Performansı } & $18-25$ & 68 & 3.9081 & 0.83521 & \multirow{5}{*}{.525} & \multirow{5}{*}{0.665} \\
\hline & $26-35$ & 167 & 3.9805 & 0.48857 & & \\
\hline & $36-45$ & 93 & 4.0296 & 0.78958 & & \\
\hline & 46 ve üzeri & 34 & 3.8971 & 1.03740 & & \\
\hline & Genel ortalama & 362 & 3.9717 & 0.70617 & & \\
\hline
\end{tabular}

$* \mathrm{P}<0.05$

Eğitim durumu değişkenine göre ortalama farkları sonuçları Tablo 5'de verilmiştir. 0.05 önem seviyesinde, iş doyumunda ve iş performanslarında bir farklılaşmanın olduğu tespit edilmiştir. Farklılaşmanın hangi gruplardan kaynaklandığını belirlemek için yapılan Duncan testi sonuçlarına göre lisansüstü eğitim derecesine sahip kişilerde gerek iş doyumunun gerekse performanslarının yüksek olduğu tespit edilmiştir. "Çalışanların eğitim durumlarına göre iş doyumları ve iş performansları arasında fark vardır $\left(\mathrm{H}_{4}\right)$ " hipotezi kabul edilmiştir. 
Tablo 5.Eğitim durumu değişkenine göre ortalama farkları

\begin{tabular}{|c|c|c|c|c|c|c|}
\hline & Eğitim Düzeyi & $\mathbf{N}$ & Ortalama & Std. Sapma & $\mathbf{F}$ & $\mathbf{P}$ \\
\hline \multirow{7}{*}{ İş Doyumu } & illkokul & 62 & 3.3661 & 0.68039 & \multirow{7}{*}{2.349} & \multirow{7}{*}{$0.041^{*}$} \\
\hline & Ortaokul & 47 & 3.1362 & 0.76873 & & \\
\hline & Lise & 125 & 3.2512 & 0.68857 & & \\
\hline & Önlisans & 43 & 2.9919 & 0.90165 & & \\
\hline & Lisans & 77 & 3.1214 & 0.82611 & & \\
\hline & Lisansüstü & 8 & 3.7125 & 0.42908 & & \\
\hline & Genel ortalama & 362 & 3.2077 & 0.75936 & & \\
\hline \multirow{7}{*}{ İş Performansı } & İlkokul & 62 & 4.1573 & 0.70017 & \multirow{7}{*}{4.468} & \multirow{7}{*}{$0.001^{*}$} \\
\hline & Ortaokul & 47 & 3.7181 & 0.87789 & & \\
\hline & Lise & 125 & 4.0640 & 0.65061 & & \\
\hline & Önlisans & 43 & 3.6977 & 0.86870 & & \\
\hline & Lisans & 77 & 3.9416 & 0.47796 & & \\
\hline & Lisansüstü & 8 & 4.3438 & 0.59668 & & \\
\hline & Genel ortalama & 362 & 3.9717 & 0.70617 & & \\
\hline
\end{tabular}

$* \mathrm{P}<0.05$

Çalışma süresi değişkenine göre ortalama farkları sonuçları Tablo 6'da gösterilmiştir. 0.05 önem seviyesinde, iş doyumunda ve iş performanslarında bir farklılaşmanın olduğu tespit edilmiştir. Farklılaşmanın hangi gruplardan kaynaklandığını belirlemek için yapılan Duncan testi sonuçlarına göre 11-16 yıl arasında sektörde çalışan kişilerin iş doyumu düşükken, 20 yıl ve üzeri çalışanların iş doyumları yüksektir. iş̧ performansı açısından ise 16-20 yıl çalışanların yüksek iken, 11-15 yıl arasında çalışanların düşük olduğu tespit edilmiştir. "Çalışanların sektörde çalışma süresine göre iş doyumları ve iş performansları arasında fark vardır $\left(\mathrm{H}_{5}\right)$ " hipotezi kabul edilmiştir.

Tablo 6. Çalışma süresi değişkenine göre ortalama farkları

\begin{tabular}{|c|c|c|c|c|c|c|}
\hline & Çalışma Süresi & $\mathbf{N}$ & Ortalama & Std. Sapma & $\mathbf{F}$ & $\mathbf{P}$ \\
\hline \multirow{6}{*}{ İş Doyumu } & $0-5 \mathrm{yıl}$ & 154 & 3.2490 & 0.82568 & \multirow{6}{*}{4.262} & \multirow{6}{*}{$0.002 *$} \\
\hline & 6-10 yıl & 78 & 3.2109 & 0.50257 & & \\
\hline & $11-15$ yıl & 49 & 2.8245 & 0.91743 & & \\
\hline & $16-20 \mathrm{yll}$ & 22 & 3.2773 & 0.91048 & & \\
\hline & 20 ve üstü & 59 & 3.3881 & 0.54317 & & \\
\hline & Genel ortalama & 362 & 3.2077 & 0.75936 & & \\
\hline \multirow{6}{*}{ İş Performansı } & $0-5$ yıl & 154 & 3.9302 & 0.72169 & \multirow{6}{*}{3.960} & \multirow{6}{*}{$0.004 *$} \\
\hline & 6-10 yıl & 78 & 3.9840 & 0.50055 & & \\
\hline & $11-15$ yıl & 49 & 3.7500 & 0.87649 & & \\
\hline & $16-20$ yıl & 22 & 4.4091 & 0.45346 & & \\
\hline & 20 ve üstü & 59 & 4.0847 & 0.74511 & & \\
\hline & Genel ortalama & 362 & 3.9717 & 0.70617 & & \\
\hline
\end{tabular}

$* P<0.05$

Katılımcıların çalıştıkları işletmelerin bulundukları il değişkenine göre yapılan Varyans Analizi sonuçları Tablo 7'de verilmiştir. 0.05 önem seviyesinde, iş doyumu ve iş performanslarında bir farklılaşmanın olup olmadığı 0.05 önem seviyesinde iş performansı değişkeni ortalamalarında bir farklılaşma bulunamazken, iş doyumu değişkeni açısından bir farklılaşma tespit edilmiştir. Farklılaşmanın hangi yaş grubundan kaynaklandığını bulmak için yapılan Duncan testinde ise farklılaşmanın Denizli ilinde bulunan çalışanlardan kaynaklandığı görülmüştür. Denizli ilinde bulunan işletmelerde çalışanların iş doyumunun diğer illerdekine göre daha yüksek olduğu tespit edilmiştir. Bu durumda, çalışanların işletmelerinin bulundukları illere göre iş doyumu açısından fark olduğu tespit edilerek, $\mathrm{H}_{6}$ hipotezi kabul edilmiştir. 
Tablo 7.Katııımcıların çalıştıkları işletmelerin ili değişkenine göre ortalama farkları

\begin{tabular}{|c|c|c|c|c|c|c|}
\hline & iller & $\mathbf{N}$ & Ortalama & Std. Sapma & $\mathbf{F}$ & $\mathbf{P}$ \\
\hline \multirow{6}{*}{ İş Doyumu } & Düzce & 54 & 3.2231 & 0.78246 & \multirow{6}{*}{3.121} & \multirow{6}{*}{$0.015^{*}$} \\
\hline & İstanbul & 136 & 3.2033 & 0.76942 & & \\
\hline & Çanakkale & 56 & 3.0402 & 0.82646 & & \\
\hline & Kayseri & 82 & 3.1567 & 0.73677 & & \\
\hline & Denizli & 34 & 3.6000 & 0.46791 & & \\
\hline & Genel ortalama & 362 & 3.2077 & 0.75936 & & \\
\hline \multirow{6}{*}{ İş Performansı } & Düzce & 54 & 4.0185 & 0.71680 & \multirow{6}{*}{1.464} & \multirow{6}{*}{0.213} \\
\hline & İstanbul & 136 & 4.0221 & 0.72615 & & \\
\hline & Çanakkale & 56 & 3.7813 & 0.76732 & & \\
\hline & Kayseri & 82 & 3.9451 & 0.68271 & & \\
\hline & Denizli & 34 & 4.0735 & 0.50949 & & \\
\hline & Genel ortalama & 362 & 3.9717 & 0.70617 & & \\
\hline
\end{tabular}

$* \mathrm{P}<0.05$

Mobilya sektöründe çalışanların iş doyumu ile iş performansları arasındaki ilişki

İki değişken arasındaki ilişkinin yönü ve gücü belirlenmesinde korelasyon analizinden faydalanılmaktadır. Korelasyon katsayısı ( $r$ ) iki değişkenin arasındaki ilişkinin ölçüsünü belirlemekte ve -1 ile +1 arasında değişim göstermektedir (Bayram 2004). Mobilya sektöründe çalışan personellerin iş doyum düzeyleri ile iş performansları arasında doğrusal bir ilişki vardır hipotezi bu analiz ile test edilmiştir. Araştırmaya ait korelasyon analizi sonucu Tablo 8'de verilmiştir.

Tablo 8. Korelasyon analizi sonuçları

\begin{tabular}{llll}
\hline & Pearson Korelasyon & İş performansı & \\
Katsayısı & 1 & $0.499^{* *}$ \\
iş doyumu & Sig. (2-tailed) & & 0.000 \\
& $\mathrm{~N}$ & 362 & 362 \\
& $\begin{array}{l}\text { Pearson Korelasyon } \\
\text { Katsayısı }\end{array}$ & $0.499^{* *}$ & 1 \\
iş performansı & Sig. (2-tailed) & 0.000 & \\
& $\mathrm{~N}$ & 362 & 362 \\
\hline
\end{tabular}

** Korelasyon 0.01 seviyesinde önemlidir

Tablo 8'de görüleceğe üzere, mobilya sektöründe çalışanların iş doyumu ile iş performansları arasındaki 0.01 seviyesinde pozitif yönlü ve kuvvetli bir ilişki saptanmıştır. Diğer bir ifade ile çalışanların iş doyumu düzeylerinde artış gözlendikçe iş performans düzeylerinde de artış gözlenmektedir. Ya da iş doyum düzeylerinde azalma oldukça performanslarında da azalma olmaktadır. Dolayısıyla çalışma kapsamında oluşturulan $\mathrm{H}_{7}$ hipotezi kabul edilmiştir.

Tablo 10. iş̧ doyumu ile iş performans arasındaki regresyon analizi sonuçları

\begin{tabular}{llll}
\hline $\begin{array}{l}\text { Korelasyon } \\
\text { Katsayısı }(\mathbf{r})\end{array}$ & $\begin{array}{l}\text { Belirleme } \\
\text { Katsayısı }\left(\mathbf{R}^{2}\right)\end{array}$ & $\begin{array}{l}\text { Düzeltilmiş } \\
\text { Belirleme } \\
\text { Katsayısı } \\
\left.\text { (Adjusted } \mathbf{R}^{2}\right)\end{array}$ & $\begin{array}{l}\text { Standart } \\
\text { Sapma }\end{array}$ \\
\hline 0.499 & 0.249 & 0.247 & 0.65876 \\
\hline
\end{tabular}

İki değişken arasındaki ilişkinin fonksiyonel şekli ile ilgilenildiğinde regresyon analizi uygulanmaktadır. Diğer bir ifade ile bağımsız bir değişkenin bağımlı değişkeni hangi düzeyde açıklayabileceği regresyon analizi ile saptanmaktadır (Bayram 2004). Çalışmada yer alan "iş doyumu" bağımlı değişkeni ile "iş performans" değişkeni regresyon analizine tabi tutulmuş ve iş doyumu değişkeninin iş performansı değişkenini etkileme düzeyi saptanmıştır. İş doyumunun, iş performansını açıklama düzeyi (Düzeltilmiş $R^{2}=0.247$ ) olarak tespit edilmiştir.

\section{SONUÇ ve TARTIŞMA}

Bu araştırma, Türkiye'de mobilya sektöründe çalışan personelin iş doyumu ve iş performansları arasındaki 
ilişkiyi belirlemeye yönelik olarak hazırlanmıştır. Elde edilen sonuçları şu şekilde sıralanabilir;

Mobilya sektöründe çalışanların iş doyumu ile iş performansları arasındaki pozitif yönlü ve kuvvetli bir ilişki tespit edilmiştir $(r=0.499, P<0.01)$. Başka bir deyişle çalışanların iş doyumu düzeylerinde artış oldukça, iş performans düzeylerinde de artış olmaktadır. Araştırmaya katılan mobilya sektöründe çalışanların iş doyumları ve iş performansları algıları cinsiyetlerine göre anlamlı farklılık gösterirken medeni durumlarına göre iş doyum ve iş performans algıları arasında anlamlı bir farkın olmadığı anlaşımıştır. Sektöründe çalışanların yaşlarına göre iş doyumları arasında anlamlı bir fark tespit edilirken, iş performans algıları açısından anlamlı bir fark bulunamamıştır. İş doyumları ve iş performansları algıları eğitim düzeylerine ve çalışma sürelerine göre anlamlı fark gösterdiği tespit edilmiştir. Araştırmaya katılanların çalıştıkları işletmelerin illere göre iş doyumu algıları açısında anlamlı bir fark bulunurken, iş performans algıları açısından ise anlamlı bir fark bulunmamıştır. Bu sonuçlara göre çalışma kapsamında incelenen araştırmalar çerçevesinde literatürle uyumlu sonuçların ortaya çıktığı söyleyebilir (Yılmaz ve Murat 2008; Koç ve ark. 2009; Köroğlu 2012).

Literatürde, çalışanların iş tatmin düzeyini etkileyen faktörlerin bireysel ve örgütsel faktörler olarak iki grup altında toplandığı belirtilmektedir. Bireysel faktörler ya da kişisel faktörler; bireylerin farklı düzeyde tatmin elde etmelerini sağlayan; yaş, cinsiyet, eğitim düzeyi, mesleki konum ve kıdem, kişilik, zekâ, hizmet süresi, medeni durum ve benzeri etkenlerdir (Serinkan ve Bardakçı 2007; Çevik ve Korkmaz 2014). Bu araştırmanın sonucunda, iş doyumları ve iş performanslarının cinsiyete, eğitim düzeyi, yaş ve kıdem göre farklılık gösterdiği, fakat medeni duruma göre herhangi bir istatiksel farklılığın olmadığı tespit edilmiştir. Yılmaz vd. (2009) çalışanların çalışma performanslarını yükseltmek açısından, kurumların çalışanların iş doyumunu etkileyen temel faktörlerin neler olduğunu bilmesinin önemli olduğunu belirtmiş ve çalışanların yeterli bir ücret elde etmesi, iş yerindeki çalışma koşullarının iyileştirilmesi, eğitimine, kişisel gelişmelerine, bağımsızlığına, yaratıcılığına ve saygınlığına önem vermelerinin iş doyumu ve performans arttıracağını belirtmiştir. Eğinli (2009) kamu sektöründe, özel sektöre göre iş doyumunun daha fazla olduğunu ve hem kamu hem de özel sektör çalışanlar açısından ücretin iş doyumu için öncelikli bir öneme sahip olduğu, bunu işten hoşlanma ve çalışma koşullarının takip ettiğini açıklamıştır.

Mobilya sektörü, ülkemizde yıllar içinde birçok açıdan önemli olumlu gelişmeler sağlayarak, yüksek katma değer üreten, ileri bağlantılarıyla diğer sektörler için önem arz eden bir sanayi dalı olarak yerini almıştır. Yine, ana hammadde olarak ahşabı veya diğer orman ürünlerini kullanan sektör, bu ürünlerin şeklini değiştirerek faydalııı derecesini artırmakta ve hem ülke ekonomisi hem de ormanların sürekliliği ile yakından ilgili olmuştur (Anonim 2015b). Fakat sektörde kronikleşen çeşitli sorunlar da halen varlığını sürdürdüğü belirtilmektedir. Bu sorunlardan en önemli olanı personel devir hızının oldukça yüksek olması, kalifiye eleman temin edilememesi ve çalışan personellerin performans düzeylerinin düşük olması olarak karşımıza çıkmaktadır (Anonim 2013a). Aras ve ark. (2007) mobilya sektöründe yeterli bilgi ve beceriye sahip personelin önemli olduğunu ve işletmelerin çalışanlardan yüksek performans bekleyebilmesi için uygun çalışma koşullarını sağlaması gerektiğini vurgulamıştır. Bu araştırma sonuçlarına göre sektörde faaliyet gösteren işletmelerin başarısı için son derece önemli bir yönetim konusu olan iş doyumunun, mobilya üretiminde çalışan personellerin performans düzeyleri ile ilişkisinin bulunduğu ortaya çıkmıştır. Nitekim, üretim faktörlerinden bir tanesi de emektir. İşletme faaliyetlerini gerçekleşebilmesi çalışanlara bağlıdır. Günümüzde birçok işletme rekabet üstünlüğü elde edebilmek için sürekli olarak gelişmeyi ve sonuçta da verimliliği artırmayı hedeflemektedir (Zerenler, 2005). Yani küresel rekabet ortamında işletmelerin kârlı ve avantajlı olmaları emek faktörünün etkin ve verimli çalışmasına bağlıdır (Örücü ve ark. 2010). Günümüzde üretim maliyetlerinin ağırlıklı bölümünü işçilik maliyetleri oluşturmaktadır. Yüksek maliyet ise karlılığı olumsuz etkilemektedir. İşçilik maliyetlerinin düşürülebilmesi için iş gücü verimliliğinin sağlanması ve etkin halde kullanılması ile gerçekleşebilir. Verimlilik artırıcı faktörler incelenirken veya değerlendirilirken dikkat edilmesi gereken en önemli unsur insan faktörüdür (Taşcı 2011). 
Insan doğası gereği yalnız yaşayamaz ve çevresi ile etkileşim halindedir. Sosyal bir varlıktır. Sosyal bir varlık olması belirli ihtiyaçları ve gereksinimleri ortaya çıkarır. $\mathrm{Bu}$ intiyaç ve gereksinimleri karşılanması hayat doyumlarını arttırdığı belirtilmektedir (Dikmen 1995).

Aydın ve Tiryaki (2015) tarafından mobilya endüstrisinde yürütülen bir araştırmada, insan odaklı yönetim uygulamalarının, çalışanların iş tatminini ve motivasyonu artırıcı yönde etkisinin olabileceği tespit edilmiştir. Ayrıca, aynı çalışmada mobilya işletmelerinde gerek işe alınırken gerekse alındıktan sonra bilgi ve beceri düzeyini öne çıkarma imkânı ve çalışana kendini geliştirme imkânı verilmesi, ayrıca terfi işlemlerinde adaletli bir yaklaşım içerisinde bulunması ile çalışanlarda performans artışı sağlanabileceği belirtilmiştir. Nitekim, mobilya endüstrisinde çalışanların yüksek performans sergilemesi, doğrudan ortaya çıkan ürünler ile ilişkili olup, olumlu katkılar sağlayabilecek niteliktedir. Bu yüzden çalışanların performansları üzerinde önemli bir etkiye sahip olan iş doyum düzeylerinin yüksek olması sektörün gelişimi açısından önemli bir faktör olarak görülmesinde fayda olacaktır.

\section{TEŞEKKÜR}

Bu çalışma, Muğla Sıtkı Koçman Üniversitesi, Fen Bilimleri Enstitüsü, Ağaç İşleri Endüstri Mühendisliği Anabilim Dalı'nda tamamlanan “Mobilya Endüstrisinde Çalışanların İs Doyumu ile işs Performansı Arasındaki illişkinin Araştırılması" adlı yüksek lisans çalışmasının özetidir. Çalışma, Muğla Sıtkı Koçman Üniversitesi, Bilimsel Araştırma Projeleri Koordinasyon Birimi tarafından 15/119 nolu proje ile desteklenmiş olup, bu desteklerinden dolayı teşekkür ederiz.

\section{KAYNAKLAR}

Akşit Aşık D (2010) Çalışanların iş doyumunu etkileyen bireysel ve örgütsel faktörler ile sonuçlarına ilişkin kavramsal bir değerlendirme. Türk İdare Dergisi 467:31-51.

Akgül A, Çevik O (2005) İstatistiksel Analiz Teknikleri SPSS'te İşletme Yönetimi Uygulamaları, Emek Ofset, 456s, Ankara.

Anonim (2013a) Dayanıkı tüketim ve mobilya sektör raporu. MÜsiAD, İstanbul

Anonim (2013a) Türkiye mobilya ürünleri meclisi sektör raporu. TOBB Yayın No: 2014/212, Ankara.
Anonim (2015a) Mobilya çalışma grubu raporu, Onuncu Kalkınma Planı (2014-2018). T.C. Kalkınma Bakanlığı, 88s. Ankara.

Anonim (2015b) Sürdürülebilir orman yönetimi özel ihtisas komisyonu raporu, Onuncu Kalkınma Planı (2014-2018). T.C. Kalkınma Bakanlığı, 86s. Ankara.

Aras R, İmirzi HÖ, Akın H (2007) İstanbul'daki küçük ve orta ölçekli mobilya üretim işletmelerinin sorunları ve çözüm önerileri. Politeknik Dergisi 10(1): 105-110

Aydın A, Tiryaki S (2015) Mobilya endüstrisinde yönetsel uygulamalar. Selçuk-Teknik Dergisi 14(2): 950-961.

Baş T (2005) Anket nasıl hazırlanır uygulanır değerlendirilir. 5. Baskı, Seçkin Yayıncılık, 271s. Ankara.

Bayram N (2004) Sosyal bilimlerde SPSS ile veri analizi. Ezgi Kitapevi, Bursa.

Bozkurt Ö, Bozkurt I (2008). İş tatminini etkileyen işletme içi faktörlerin eğitim sektörü açısından değerlendirilmesine yönelik bir alan araştırması. Doğuş Üniversitesi Dergisi 9 (1): 1-18

Çevik NK, Korkmaz O (2014) Türkiye'de yaşam doyumu ve iş doyumu arasındaki ilişkinin iki değişkenli sıralı probit model analizi. Niğde Üniversitesi İktisadi ve İdari Bilimler Fakültesi Dergisi 7(1): 126145.

Dikmen AA (1995) iş doyumu ve yaşam doyumu ilişkisi. Ankara Üniversitesi SBF Dergisi 50(03):115-140.

Eğinli AT (2009) Çalışanlarda iş doyumu: kamu ve özel sektör çalışanlarının iş doyumuna yönelik bir araştırma. Atatürk Üniversitesi İktisadi ve İdari Bilimler Dergisi 23(3): 35-52.

Erdil O, Keskin H, İmamoğlu SZ, Serhat E (2011) Yönetim tarzı ve çalışma koşulları, arkadaşık ortamı ve takdir edilme duygusu ile iş tatmini arasındaki ilişkiler: tekstil sektöründe bir uygulama. Doğuş Üniversitesi Dergisi 5(1):17-26.

Koç H, Yazıcıoğlu I, Hatipoğlu H (2009) Öğretmenlerin iş doyum algıları ile performansları arasındaki ilişkinin belirlenmesine yönelik bir araştırma. Ondokuz Mayıs Üniversitesi Eğitim Fakültesi Dergisi 28:13-22.

Köroğlu Ö (2012) İçsel ve dışsal iş doyum düzeyleri ile genel iş doyum düzeyi arasındaki ilişkinin belirlenmesi: turist rehberleri üzerinde bir araştırma. Doğuş Üniversitesi Dergisi 13 (2):275-289.

Noe RA, Hollenbeck JR, Gerhart B, Wright PM (1997) Human resource management: gaining a kompetitife advantage. McGraw-Hill, Chicago

Örücü E, Kılıç R, Şimşir S (2010) Organizasyonlarda iş tatmini uygulamaları ve örgütsel bağ|ılığa etkisi üzerine bir araştırma. Yönetim ve Ekonomi Araştırmaları Dergisi 8(13): 1-14.

Serinkan C, Bardakçı A (2007) Pamukkale Üniversitesi'nde çalışan öğretim elemanlarının iş tatminlerine ilişkin bir araştırma. Selçuk Üniversitesi Karaman IiBF Dergisi 12(9): 152-163.

Sevimli F, İşcan ÖF (2005) Bireysel ve iş ortamına ait etkenler açısından iş tatmini. Ege Akademik Bakış5(1-2):55-64.

Taşcı F (2011) Verimlilik artışında emek etkinliği üzerine bir yaklaşım: ah-me-t modeli. Sosyal Siyaset Konferansları Dergisi (61): 177199.

Tekeli S, Paşaoğlu D (2012) Türkiye'de banka çalışanlarının performansını etkileyen faktörler: Eskişehir ili kamu ve özel banka örneği. Organizasyon ve Yönetim Bilimleri Dergisi 4(2):177-189. 
Tolunay A, Türkoğlu T (2014) Perspectives and attitudes of forest products industry companies on the chain of custody certification: a case study from Turkey. Sustainability 6(2): 857871.

Toker H, Ergun ME, Baysal E, Türkoğlu T (2016) Meslek yüksekokullarındaki mobilya ve dekorasyon programlarının sorunları ve çözüm önerileri. In. Proc. V. Uluslararası Meslek Yüksekokulları Sempozyumu, Kosava, pp. 11-15.

Turunç Ö (2010) Organizasyonlarda kontrol algılamalarının örgütsel özdeşleşme ve iş performansına etkisi. Cukurova Üniversitesi Iktisadi ve İdari Bilimler Dergisi 11(1): 251-269.

Tutar H, Altınöz M (2010) Örgütsel iklimin işgören performansı üzerine etkisi: ostim imalat işletmeleri çalışanları üzerine bir araştırma. Ankara Üniversitesi SBF Dergisi 65(02): 196-218.

Türker MF, Gavcar E (1993) Endüstrilerarası işlemler tabloları yardımıyla orman ürünleri endüstrilerinin ekonomik analizi. In. Proc. II. Ulusal Orman Ürünleri Endüstri Kongresi (ORENKO 93), Trabzon, pp. 266-275.

Türkoğlu T, Tolunay A (2013) Türkiye'deki orman ürünleri ithalatçısı işletmelerin sertifikalı orman ürünlerine ilişkin görüşleri. SDÜ Orman Fakültesi Dergisi 14 (2):95-101.

Quick JC, Nelson DL (1995) Organizational behavior: foundations, realities, and challenges. West Company, New York
Yıldırım S (1995) Yöneticilerin algıladıkları iş tatmini. Ankara Üniversitesi SBF Dergisi 50(01):441-451.

Yılmaz E, Koçak Z (2008) Doğu Akdeniz Ormancılık Araştırma Müdürlüğü çalışanlarına yönelik iş doyumu araştırması. Çevre ve Orman Bakanlığı, Doğu Akdeniz Ormancılık Araştırma Müdürlüğü Yayın No: 364/48, Çeşitli Yayın No: 8, 56 s., Tarsus.

Yılmaz E, Daşdemir I, Karabulut S, Koçak Z, Polat O (2009). Orman Genel Müdürlüğü taşra teşkilatı çalışanlarının iş doyumunu etkileyen faktörler: Mersin Orman Bölge Müdürlüğü ve buna bağlı orman işletme müdürlükleri örneği. Çevre ve Orman Bakanlığı, Doğu Akdeniz Ormancılık Araştırma Müdürlüğü Yayın No: 387/52, Teknik Bülten No: 30, ISBN 978-605-393-056-3, 65 s., Tarsus.

Yılmaz Z, Murat M (2008) illköğretim okulu yöneticilerinin iş doyumları ile örgütsel stres kaynakları arasındaki ilişki. Fırat Üniversitesi Sosyal Bilimler Dergisi 18(2):203-222.

Yılmaz H, Karahan A (2010) Liderlik davranışı, örgütsel yaratıcılık ve işgören performansı arasındaki ilişkilerin incelenmesi: Uşak'ta bir araştırma. Yönetim ve Ekonomi: Celal Bayar Üniversitesi Iktisadi ve İdari Bilimler Fakültesi Dergisi 17(2): 145-158.

Zerenler, M (2005) Performans Ölçüm Sitemleri Tasarımı ve Üretim Sistemlerinin Performansının Ölçümüne Yönelik Bir Araştırma, AiBÜ-iiBF Ekonomik ve Sosyal Araştırmalar Dergisi (Bahar, 1): 136. 